\title{
ADVERSITY QUOTIENT REMAJA YANG MENGALAMI BROKEN HOME
}

\author{
Zelin Heris Dwi Safitri ${ }^{1}$, Mulia Marlita Lasutri Tama ${ }^{2}$, \\ Mahasiswa Universitas Bina Darma ${ }^{1}$, Dosen Universitas Bina Darma ${ }^{2}$ \\ Jalan Jenderal Ahmad Yani No.3 Palembang \\ Sur-el: zelin.razelma@gmail.com¹,mulya.hedi399@gmail.com²
}

\begin{abstract}
The purpose of the research is to find out the adversity quotient of adolescents who experienced broken home. What factors influence adversity quotient of adolescents who experience a broken home, and how the description of adversity quotient adolescents who experience a broken home. This study used a qualitative research design and used a case study approach to be able to find out adversity quotient of adolescents who experience broken home. In this study, researchers used 6 sources 2 people as research subjects and 4 people as informants to know from each subject. Rhe results of this study found that adversity quotient adolescents who wxperience broken home have adversity quotient that is not much different. The first subject has four dimentions of adversity quotient, while the second subject only has three of the four dimentions of adversity quotient, each dimention possessed by several factors, namely beliefs, talents, character, passion/willingness, education and environment.
\end{abstract}

Keyword: Adversity Quotient, Adolescence, Broken Home

Absrtak: Penelitian ini bertujuan untuk mengetahui adversity quotient remaja yang mengalami broken home. Faktor apa saja yang mempengaruhi adversity quotient remaja yang mengalami broken home, serta bagaimana gambaran adversity quotient remaja yang mengalami broken home. Penelitian ini menggunakan desain penelitian kualitatif serta menggunakan pendekatan studi kasus untuk dapat mengetahui adversity quotient remaja yang mengalami broken home. Dalam penelitian ini, peneliti menggunakan 6 sumber. 2 orang sebagai subjek penelitian dan 4 orang sebagai informan tahu dari masing-masing subjek. Hasil penelitian ini menemukan bahwa adversity quotient remaja yang mengalami broken home memiliki adversity quotient yang tidak jauh berbeda. Subjek pertama memiliki empat dimensi adversity quotient, sementara subjek kedua hanya memiliki tiga dari empat dimensi adversity quotient. Setiap dimensi yang dimiliki oleh subjek juga dipengaruhi oleh beberapa faktor yaitu keyakinan, bakat, karakter, hasrat/kemauan, pendidikan dan lingkungan.

Kata Kunci: Adversity Quotient, Remaja, Broken Home

Masalah yang dianggap paling besar yang

\section{PENDAHULUAN}

Masa remaja merupakan masa transisi dari masa kanak-kanan menuju masa dewasa. Masa remaja (adolescene) memiliki makna yang lebih luas mencakup kematangan mental, emosional, sosial dan fisik (Hurlock. 1999). dialami remaja salah satunya adalah masalah keluarga. Keluarga adalah wadah bagi anak untuk dapat berkembang dan tumbuh baik secara fisik maupun psikologis. Dalam keluarga setiap orangtua pasti ingin memberikan yang terbaik untuk anak-anaknya. Akan tetapi, dalam kenyataannya tidak selalu seperti yang diinginkan. Adanya masalah disorganisasi dalam keluarga dapat menjadi andil yang tidak menguntungkan 
bagi anak-anak terutama remaja, kondisi seperti ini disebut dengan istilah broken home.

Broken home adalah keluarga yang mengalami disharmonis antara ayah dan ibu (Ulwan, 2002). Pernyataan ini dipertegas oleh Atriel (2008) yang mengatakan bahwa broken home merupakan suatu kondisi keluarga yang tidak harmonis dan orangtua tidak dapat lagi menjadi tauladan yang baik untuk anakanaknya. Bisa jadi mereka bercerai, pisah ranjang, atau keributan yang terus menerus terjadi dalam keluarga.

Dalam permasalahan ini, anak-anak terutama yang masih remaja menjadi korban sesungguhnya. Keluarga yang broken home dapat menyisakan luka yang mendalam bagi anak-anak terutama remaja. Tetapi, ada juga remaja yang mampu menghadapi dan mengatasi kesulitan yang dialaminya sehingga tidak berdampak secara mendalam ke dalam kehidupannya. Kondisi seperti ini disebut juga dengan adversity quotient.

Adversity quotient (Stoltz, 2000) merupakan kemampuan seseorang dalam mengamati kesulitan dan mengelolah kesulitan tersebut dengan kecerdasan yang dimiliki sehingga menjadi sebuah tantangan untuk menyelesaikannya.

\section{Menurut Stolzt (2005), Adversity}

Quotient merupakan suatu kemampuan yang terdiri dari empat dimensi, yaitu: 1) Kendali diri (Control) yaitu kemampuan individu dalam mempengaruhi secara positif suatu situasi, serta mampu mengendalikan respon terhadap situasi, dengan pemahaman awal bahwa sesuatu apapun dalam situasi apapun individu dapat melakukannya; 2) Asal-usul dan pengakuan (Origin-Ownership) yaitu suatu kemampuan individu dalam menempatkan perasaan dirinya dengan berani menanggung akibat dari situasi yang ada, sehingga menciptakan pembelajaran dalam melakukan perbaikan atas masalah yang terjadi; 3) Jangkauan (Reach) yaitu kemampuan individu dalam menjangkau dan membatasi masalah agar tidak menjangkau bidang-bidang yang lain, dimensi ini melihat sejauh mana individu membiarkan kemalangan menjangkau bidang lain dalam hidupnya seperti, pekerjaan dan hidup individu; 4) Daya tahan (Endurance) yaitu kemampuan individu dalam mempersepsi kesulitan, dan kekuatan dalam menghadapi kesulitan tersebut dengan menciptakan ide dalam pengatasan masalah sehingga ketegaran hati dan keberanian dalam penyelesaian masalah dapat terwujud.

Subjek pertama DB merupakan seorang remaja wanita berusia 19 tahun yang memiliki tinggi badan sekitar $150 \mathrm{~cm}$ dengan tubuh yang sedikit berisi. DB adalah wanita yang berhijab. Orangtua DB bercerai ketika ia berusia 12 tahun, waktu itu DB masih duduk dibangku SMP kelas satu.

Subjek kedua yaitu S, S adalah seorang remaja wanita dari keluarga broken home dimana dalam hal ini kedua orangtuanya bercerai. S memiliki tinggi badan sekitar 167 $\mathrm{cm}$ dan berat $40 \mathrm{~kg}$. S memiliki kulit sawo matang dan rambut panjang yang lurus. $\mathrm{S}$ adalah anak ke tiga dari tiga bersaudara. Umur S saat ini 15 tahun.

Adversity quotient tidak datang dengan sendirinya, adanya faktor yang mempengaruhi. 
Stoltz (2000) mengatakan bahwa ada dua faktor yang mempengaruhi adversity quotient seseorang, yaitu faktor internal dan faktor eksternal. Faktor internal meliputi genetika, keyakinan, bakat, hasrat atau kemauan, karakter,kinerja, kecerdasan, dan kesehatan. Sedangkan faktor eksternal meliputi pendidikan dan lingkungan.

Setelah mengetahui dan menelaah berbagai penjabaran tentang broken home serta adversity quotient remaja yang mengalami broken home. Berdasarkan hal itu pula muncul pertanyaan penelitian yaitu:

1. Bagaimana gambaran Adversity Quotient pada remaja yang mengalami Broken Home?

2. Faktor-faktor apa saja yang mempengaruhi Adversity Quotient pada remaja yang mengalami Broken Home

\section{METODE PENELITIAN}

Penelitian ini menggunakan metode pendekatan kualitatif. Pendekatan kualitatif merupakan prosedur penelitian yang menghasilkan data deskriptif, ucapan atau tulisan dan perilaku yang dapat diamati dari orang-orang (subjek) itu sendiri (Bogdan dan Taylor, dalam Ahmadi, 2014).

Penelitian ini berorientasi pada seorang remaja yang mengalami broken home yang memiliki suatu keunikan di dalam dirinya. Peneliti lebih memfokuskan penelitian ini pada adversity quotient dengan menggunakan pendekatan studi kasus. Dalam penelitian ini, peneliti menggunakan 6 orang sumber, 2 sebagai subjek penelitian, dan 4 sebagai informan tahu dari masing-masing subjek penelitian.
Teknik yang digunakan dalam penelitian ini berupa gabungan dari teknik observasi, wawancara, dan dokumentasi. Dalam menguji keabsahan data, metode penelitian kualitatif dengan menggunakan validitas dan verifikasi data dengan menggunakan trianggulasi data. Trianggulasi terbagi menjadi trianggulasi sumber, trianggulasi teknik pengumpulan data, trianggulasi waktu, dan trianggulasi teori (Sugiono 2016).

\section{HASIL DAN PEMBAHASAN}

1. Subjek 1 (DB)

1.1. Analisa dan Pembahasan Gambaran Adversity Quotient Remaja Yang Mengalami Broken Home (DB)

Adapun empat dimensi adversity quotient yang dipaparkan oleh Stoltz (2005) yang terdiri dari a) control atau kendali diri adalah kemampuan seseorang dalam mengendalikan dan mengelola sebuah peristiwa yang menimbulkan kesulitan di masa mendatang. Control atau kendali diri mempunyai dua sisi. Pertama, sejauh mana anda mampu untuk secara positif mempengaruhi suatu situasi. Kedua, sejauh mana anda dapat mengendalikan tanggapan anda sendiri terhadap suatu situasi; b) originownership (asal-usul dan pengakuan) dimensi ini menjelaskan sejauh mana seseorang mengandalkan diri sendiri terhadap suatu permasalahan untuk memperbaiki situasi yang dihadapi ketika mendapati bahwa kesalahan tersebut berasal dari dirinya, atau sejauh mana seseorang mempermasalahkan orang lain atau lingkungan yang menjadi sumber kesulitan atau kegagalan seseorang. Ownership mengungkap sejauh mana seseorang mengakui akibat-akibat 
kesulitan dan kesediaan seseorang untuk bertanggung jawab atas kesalahan atau kegagalan tersebut. c) reach (jangkauan) dimensi ini merupakan sejauh mana kesulitan ini akan menjangkau bagian-bagian lain dari kehidupan seseorang. Hal ini menunjukkan bagaimana suatu masalah mengganggu aktivitas lainnya, sekalipun tidak berhubungan dengan masalah yang sedang dihadapi; dan d) endurance (daya tahan) yaitu sejauh mana kecepatan dan ketepatan seseorang dalam memecahkan masalah. Sehingga pada aspek ini dapat dilihat berapa lama kesulitan akan berlangsung dan berapa lama penyebab kesulitan itu akan berlangsung.

Control (kendali diri) yang terlihat dari DB adalah ia tidak memperlihatkan kesedihannya dengan orang lain terutama dengan kedua orangtuanya. Ketika DB melihat orangtuanya bertengkar ataupun sedang merasa sedih, DB lebih memilih untuk bermain ke rumah temannya untuk menghibur diri dan untuk menghindari situasi yang sedang kacau agar tidak terbawa emosi.

Sedangkan origin-ownweship (asal-usul dan pengakuan) yang ada pada diri DB adalah bahwa DB peka dengan keadaan disekitaranya. DB dapat menganalisa dan mengetahui bahwa keluarganya mengalami permasalahan walaupun di awalnya kedua orangtua DB menyembunyikan pertengkaran yang terjadi dari anak-anak mereka, namun hal itu dapat dirasakan dan diketahui oleh DB. Selain itu, DB juga turut membantu keluarganya ketika mereka sedang mengalami kesulitan ekonomi. Subjek berinisiatif untuk berjualan makanan dan mainan di masjid tempat ia mengaji. Hal ini DB lakukan untuk membantu meringankan beban dari kedua orangtuanya. DB sempat mengaku merasa malu ketika pertama kali ia jualan, namun hal tersebut tidak dihiraukan olehnya dan akhirnya DB tidak malu lagi untuk berjualan makanan dan mainan di tempat ia mengaji, terlebih lagi ketika orangtuanya memutuskan untuk bercerai hal ini membuat DB menjadi lebih bersemangat untuk berjualan. DB juga mengajukan beasiswa di sekolahnya untuk meringankan beban ekonomi keluarga, uang beasiswa yang didapatkan oleh $\mathrm{DB}$ ia gunakan untuk membeli keperluan sekolahnya dan sekolah adiknya.

Reach (jangkauan) yang muncul pada diri DB adalah walaupun DB mengalami banyak permasalahan di dalam keluarganya seperti pertengkaran dari kedua orangtuanya yang akhirnya membuat orangtuanya bercerai dan mengharuskan subjek tinggal bersama tantenya, kemudian di rumah tantenya ini subjek mendapatkan pelecehan dari pamannya sendiri berupa pelukan dan sering di intip oleh pamannya baik ketika ia mandi ataupun sedang tidur. Namun hal ini tidak mempengaruhi kehidupan sosial DB, ia masih bisa berkomunikasi dan bersosialisasi dengan orang sekitarnya dengan baik. Selain itu permasalahan ini tidak membuat prestasi subjek menurun, subjek masih bisa mempertahankan nilai-nilai hasil belajarnya.

Terakhir endurance (daya tahan), dengan berbagai permasalahan yang ada subjek dapat bertahan, tangguh dan dapat menyelesaikan setiap permasalahannya. Dari kasus pelecehan seksual yang didapatkan oleh DB yang dilakukan oleh pamannya sendiri, DB tidak diam begitu saja. Saat pertama kali hal ini terjadi, DB menceritakan kejadian yang ia alami kepada tantenya. Awalnya DB tidak menceritakan 
kejadian ini dengan orangtuanya, karena kedua orangtua DB jauh dan berada di luar kota, DB tidak ingin kedua orangtuanya sedih, kepikiran, dan merasa marah karena kejadian ini. Namun, karena pelecehan yang dilakukan oleh pamannya terulang kembahi bahkan sering terulang akhirnya DB menceritakan permasalahan ini dengan kedua orangtua dan keluarganya. Dengan ini, DB mengharapkan kejadian ini tidak akan terulang kembali. Untuk menjaga nama baik keluarga, akhirnya permasalahan ini hanya diselesaikan secara kekeluargaan dan paman DB meminta maaf kepada DB dan keluarga mereka.

\subsection{Analisa dan Pembahasan Faktor yang} Mempengaruhi Adversity Quotient Remaja Yang Mengalami Broken Home (DB)

Stoltz (2000) dalam bukunya menggambarkan potensi dan daya tahan individu dalam sebuah pohon yang disebut pohon kesuksesan. Aspek-aspek yang ada dalam pohon kesuksesan tersebut yang dianggap mempengaruhi adversity quotient seseorang, yaitu faktor internal dan faktor eksternal. Faktorfaktor internal yaitu a) Genetika, warisan genetis tidak akan menentukan nasib seseorang tetapi pasti ada pengaruh dari faktor ini. Beberapa risetriset terbaru menyatakan bahwa genetika sangat mungkin mendasari perilaku; b) Keyakinan, mempengaruhi seseorang dalam menghadapi suatu masalah serta membantu seseorang dalam mencapai tujuan hidup; c) Bakat yaitu gabungan pengetahuan, kompetensi, pengalaman, dan keterampilan; d) Hasrat atau kemauan, yaitu menggambarkan motivasi, antusias, gairah dorongan, ambisi, dan semangat; e) Karakter, merupakan bagian yang penting bagi kita untuk meraih kesuksesan dan hidup berdampingan secara damai; f) Kinerja, salah satu keberhasilan seseorang dalam menghadapi masalah dan meraih tujuan hidup dapat diukur lewat kinerja; g) Kecerdasan, bidang kecerdasan yang dominan biasanya mempengaruhi karier, pekerjaan, pelajaran, dan hobi; dan h) Kesehatan, kondisi fisik dan psikis yang prima akan mendukung seseorang dalam menyelesaikan masalah.

$$
\text { Sedangkan faktor eksternal yaitu a) }
$$

Pendidikan, pendidikan dapat membentuk kecerdasan, pembentukan kebiasaan yang sehat, perkembangan watak, keterampilan, hasrat, dan kinerja yang dihasilkan; dan b) Lingkungan, menurut Stoltz, individu yang terbiasa berada di lingkungan yang sulit akan memiliki adversity quotient yang lebih bersar karena pengalaman dan kemampuan beradaptasi yang lebih baik dalam mengatasi masalah yang dihadapi. Dari semua faktor yang mempengaruhi adversity quotient tersebut, ada beberapa faktor yang muncul pada diri DB.

Faktor pertama yaitu keyakinan, DB percaya bahwa Allah SWT tidak akan pernah memberikan cobaan diluar batas kemampuan hamba-Nya dan ia juga percaya jika Allah SWT akan selalu bersama hamba-Nya yang bersabar dan terus berusaha. Selain itu, DB juga percaya dengan kemampuan yang dimilikinya dalam menyelesaikan setiap permasalahannya. DB selalu optimis menjalani kehidupannya walaupun di dalamnya ia menemukan banyak hambatan dan persoalan yang sulit, hal ini seakan tidak menjadi hambatan DB untuk tetap ceria dan berprestasi serta memiliki hubungan yang baik dengan semua orang. 
Faktor yang kedua yaitu bakat, DB memiliki inisiatif untuk menyelesaikan permasalahan-permasalahannya. Ketika keluarganya mengalami kesulitan ekonomi, DB memiliki inisiatif untuk menyelesaikannya dengan cara berjualan makanan dan mainan di tempat ia mengaji dan DB juga mengajukan beasiswa ke sekolahnya supaya dapat meringankan beban ibunya.

Faktor ketiga yaitu hasrat/kemauan, salah satu alasan DB tetap kuat dan optimis menjalani kehidupannya adalah karena ia tidak ingin melihat kedua orangtuanya bersedih. DB tidak menunjukkan kesedihannya dengan orang lain terutama kedua orangtuanya, karene DB tidak ingin orang lain mengasihaninya dan DB tidak ingin orangtuanya merasa sedih dan bersalah karena melihat DB bersedih. DB juga berpikir bahwa bahagia adalah hak semua orang, oleh karena itu jika DB sudah merasa tidak nyaman di lingkungan rumah akibat permasalahanpermasalahan yang terjadi seperti pertengkaran kedua orangtuanya, pelecehan yang dilakukan oleh pamannya terhadap dirinya, maka DB lebih memilih untuk bermain kerumah temannya untuk menghibur diri.

Faktor keempat yaitu karakter, dalam menghadapi setiap permasalahan, DB selalu berusaha agar tetap tenang. DB berusaha untuk menyelesaikan masalahnya sendiri, namun hal ini bukan berarti DB tidak mau meminta bantuan orang lain. Menurut DB ketika permasalahan itu sudah ia rasakan semakin rumit maka ia tidak sungkan untuk meminta bantuan dengan orangorang terdekatnya. Seperti pelecehan yang dilakukan oleh pamannya terhadap dirinya, selain dengan selalu berpakaian tertutup dan selalu mengenakan hijab jika dirumah, untuk menghindari pelecehan yang didapatkannya tidak terulang, DB juga membicarakan masalah ini dengan tantenya bahkan dengan keluarga besarnya.

Faktor kelima yaitu pendidikan, selain pendidikan formal DB juga mengikuti berbagai organisasi baik di kampus maupun di desanya. Hal ini dilakukan DB untuk menyibukkan diri. Dari berbagai organisasi yang diikutinya, DB belajar kedisiplinan, kepemimpinan, dan menjadi lebih kreatif. Alasan lain DB mengikuti organisasi adalah karena menurutnya dengan mengikuti organisasi maka dapat menambah wawasan dan dapat berjumpa dengan banyak orang.

Terakhir yaitu faktor lingkungan, DB dibesarkan di dalam keluarga yang harmosis pada awalnya, namun ketika beranjak remaja kebangrutan usaha ternak puyuh ayahnya memicu pertengkaran antara kedua orangtuanya yang mengakibatkan kedua orangtuanya memutuskan untuk bercerai. Setelah perceraian kedua orangtuanya dan ibu DB menikah kembali, DB harus tinggal bersama dengan tantenya karena ketika itu keluarga tidak memperbolehkan DB dan semua saudarinya ikut bersama dengan ibunya karena alasan-alasan tertentu. Di rumah tantenya inilah DB mendapatkan pelecehan yang dilakukan oleh pamannya sendiri. Namun dari berbagai permasalahan yang terjadi di dalam kehidupan DB, hal ini tidak menghalangi DB untuk memiliki hubungan yang baik dengan semua orang. DB masih dapat bersosialisasi dengan baik dengan semua orang, baik dengan keluarga, tetangga, ataupun denga teman-temannya. Dilingkungan keluarga, tetangga, dan teman- 
temannya DB adalah sosok yang ceria dan ramah dengan semua orang.

\section{Subjek 2 (S)}

\subsection{Analisa dan Pembahasan Gambaran} Adversity Quotient Remaja Yang Mengalami Broken Home (Subjek S)

Adapun empat dimensi adversity quotient yang dipaparkan oleh Stoltz (2005) yang terdiri dari a) control atau kendali diri adalah kemampuan seseorang dalam mengendalikan dan mengelola sebuah peristiwa yang menimbulkan kesulitan di masa mendatang. Control atau kendali diri mempunyai dua sisi. Pertama, sejauh mana anda mampu untuk secara positif mempengaruhi suatu situasi. Kedua, sejauh mana anda dapat mengendalikan tanggapan anda sendiri terhadap suatu situasi; b) originownership (asal-usul dan pengakuan) dimensi ini menjelaskan sejauh mana seseorang mengandalkan diri sendiri terhadap suatu permasalahan untuk memperbaiki situasi yang dihadapi ketika mendapati bahwa kesalahan tersebut berasal dari dirinya, atau sejauh mana seseorang mempermasalahkan orang lain atau lingkungan yang menjadi sumber kesulitan atau kegagalan seseorang. Ownership mengungkap sejauh mana seseorang mengakui akibat-akibat kesulitan dan kesediaan seseorang untuk bertanggung jawab atas kesalahan atau kegagalan tersebut. c) reach (jangkauan) dimensi ini merupakan sejauh mana kesulitan ini akan menjangkau bagian-bagian lain dari kehidupan seseorang. Hal ini menunjukkan bagaimana suatu masalah mengganggu aktivitas lainnya, sekalipun tidak berhubungan dengan masalah yang sedang dihadapi; dan d) endurance (daya tahan) yaitu sejauh mana kecepatan dan ketepatan seseorang dalam memecahkan masalah. Sehingga pada aspek ini dapat dilihat berapa lama kesulitan akan berlangsung dan berapa lama penyebab kesulitan itu akan berlangsung.

Hasil gambaran adversity quotient pada subjek kedua $\mathrm{S}$, bahwa $\mathrm{S}$ memiliki tiga dimensi dari adversity quotient yaitu control (kendali diri), origin-ownership (asal-usul dan pengakuan), dan endurance (daya tahan).

Control (kendali diri) yang terlihat pada $\mathrm{S}$ adalah bahwa S lebih banyak berdiam diri di dalam kamarnya sambil mendengarkan musik memakai headset jika kedua orangtuanya sedang bertengkar. Hal ini dilakukan oleh S supaya ia tidak mendengarkan pertengkaran kedua orangtuanya. Akibatnya komunikasi antara S dan kedua orangtuanya menjadi kurang lancar, jika ada permasalahan pribadi, S lebih memilih untuk menyimpan sendiri permasalahan itu daripada bercerita dengan orangtuanya.

Origin-ownership (asal-usul dan pengakuan), $\mathrm{S}$ mengetahui permasalahan yang sedang terjadi di dalam keluarganya. $\mathrm{S}$ dapat mengetahi hal tersebut karena memang kedua orangtua $\mathrm{S}$ bertengkar secara terang-terangan di depan S dan saudarinya yang lain. Ketidak percayaan dan kesalah pahaman yang terjadi antara orangtuanya serta sikap ayah $\mathrm{S}$ yang sering memukul ibu S dan melempar barang-barang ketika sedang marah membuat kedua orangtua $\mathrm{S}$ memutuskan untuk bercerai. Permasalahan ini berdampak dengan $\mathrm{S}$, teman-teman $\mathrm{S}$ tidak mau bermain ke rumah $\mathrm{S}$ karena mereka takut. Hal ini membuat $\mathrm{S}$ selalu bermain kerumah temannya untuk menjaga hubungannya dengan semua teman-temannya tetap akrab dan baik. Selain itu, 
semenjak perceraian kedua orangtuanya $\mathrm{S}$ berinisiatif untuk tinggal secara bergantian dengan ibu dan ayahnya. Hal ini dilakukan $\mathrm{S}$ tidak ingin ibu dan ayahnya mempermasalahkan dan memperebutkan tentang $\mathrm{S}$ dan saudarinya harus tinggal bersama ibu atau ayahnya. S tinggal secara bergantian semejak ibu dan ayahnya bercerai sampai sekarang.

Endurance (daya tahan), perceraian kedua orangtua $\mathrm{S}$ membuat kondosi keluarga $\mathrm{S}$ tidak membaik, bahkan bukan hanya kedua orang tuanya saja yang bertengkar namun kedua keluarga dari ibu dan ayahnya pun juga ikutikutan bertengkar dan saling menjelek-jelekkan satu sama lain. Ketika ada anggota keluarga yang menjelek-jelekkan orangtuanya, maka $\mathrm{S}$ akan membela kedua orangtuanya, karena menurut $\mathrm{S}$ walau bagaimanapun juga, mereka masih orangtua kandungnya da $\mathrm{S}$ tidak ingin orang lainberbicara hal buruk tentang kedua orangtuanya.

\subsection{Analisa dan Pembahasan Faktor} Adversity Quotient Remaja Yang Mengalami

\section{Broken Home (S)}

Stoltz (2000) dalam bukunya menggambarkan potensi dan daya tahan individu dalam sebuah pohon yang disebut pohon kesuksesan. Aspek-aspek yang ada dalam pohon kesuksesan tersebut yang dianggap mempengaruhi adversity quotient seseorang, yaitu faktor internal dan faktor eksternal. Faktorfaktor internal yaitu a) Genetika, warisan genetis tidak akan menentukan nasib seseorang tetapi pasti ada pengaruh dari faktor ini. Beberapa risetriset terbaru menyatakan bahwa genetika sangat mungkin mendasari perilaku; b) Keyakinan, mempengaruhi seseorang dalam menghadapi suatu masalah serta membantu seseorang dalam mencapai tujuan hidup; c) Bakat yaitu gabungan pengetahuan, kompetensi, pengalaman, dan keterampilan; d) Hasrat atau kemauan, yaitu menggambarkan motivasi, antusias, gairah dorongan, ambisi, dan semangat; e) Karakter, merupakan bagian yang penting bagi kita untuk meraih kesuksesan dan hidup berdampingan secara damai; f) Kinerja, salah satu keberhasilan seseorang dalam menghadapi masalah dan meraih tujuan hidup dapat diukur lewat kinerja; g) Kecerdasan, bidang kecerdasan yang dominan biasanya mempengaruhi karier, pekerjaan, pelajaran, dan hobi; dan h) Kesehatan, kondisi fisik dan psikis yang prima akan mendukung seseorang dalam menyelesaikan masalah.

Sedangkan faktor eksternal yaitu a) Pendidikan, pendidikan dapat membentuk kecerdasan, pembentukan kebiasaan yang sehat, perkembangan watak, keterampilan, hasrat, dan kinerja yang dihasilkan; dan b) Lingkungan, menurut Stoltz, individu yang terbiasa berada di lingkungan yang sulit akan memiliki adversity quotient yang lebih bersar karena pengalaman dan kemampuan beradaptasi yang lebih baik dalam mengatasi masalah yang dihadapi. Dari semua faktor yang mempengaruhi adversity quotient tersebut, ada beberapa faktor yang muncul pada diri S.

Faktor pertama yaitu keyakinan, S percaya dengan kemampuannya dalam menyelesaikan setiap permasalahan yang sedang ia hadapi. Menurut S jika ia tidak kuat dan tidak yakin dapat menyelesaikan serta melewati permasalahan yang terjadi pada dirinya, maka 
oranglain juga tidak akan bisa percaya dan tidak akan bisa mengautkan dan membantunya.

Faktor kedua yaitu bakat, ketika kedua orangtua $\mathrm{S}$ memutuskan untuk bercerai, $\mathrm{S}$ berinisiatif untuk tinggal secara bergantian antara ibu dan ayahnya. Hal ini dilakukan S karena ia tidak ingin orangtuanya mempermasalahkan hal tersebut.

Faktor ketiga yaitu karakter, S lebih memilih untuk berusa sendiri terlebih dahulu dalam menyelesaikan setiap permasalahan yang sedang ia hadapi. Namun walaupun demikian, $\mathrm{S}$ juga tidak akan sungkan meminta bantuan oranglain jika ia merasa membutuhkannya.

Faktor keempat yaitu pendidikan, selain pendidikan formal $\mathrm{S}$ juga mengikuti organisasi pencak silat. S mengikuti pencak silat supaya dapat melindungi keluarganya terutama ibunya. Menurut S semenjak ia mengikuti pencak silat, ia lebih dapat mengontrol emosi, dan ia juga dapat menyalurkan emosinya menjadi hal yang positif serta dapat berjumpa dengan banyak orang.

Terakhir yaitu lingkungan, dari kecil $\mathrm{S}$ memang dibesarkan dalam lingkungan yang tidak harmonis, dimana kedua orangtua $\mathrm{S}$ sering bertengkar secara terang-terangan didepan anakanak mereka. Bahkan setelah perceraian orangtuanya pun tidak membuat kondisi keluarga $\mathrm{S}$ menjadi lebih baik, perceraian orangtuanya malah membuat keluarga ibu dan keluarga ayah $\mathrm{S}$ menjadi ikut-ikutan bertengkar dan saling menjelekkan. Semejak orangtuanya bercerai $\mathrm{S}$ tinggal secara bergantian antara ibu dan ayahnya. Walaupun demikian, permasalahan yang terjadi tidak memberikan dampak yang berarti untuk $\mathrm{S}$ dalam sosialisasi. S memiliki hubungan yang baik dengan keluarganya terlepas dari sikap keluarga yang sering menjelek-jelekkan orangtuanya, tetangga, dan teman-temannya.

\section{SIMPULAN}

Berdasarkan hasil analisis yang dilakukan peneliti dapat ditarik kesimpulan bahwa adanya perbedaan mengenai dinamika psikologis yang dimiliki oleh kedua subjek mengenai adversity quotient remaja yang mengalami broken home. Adanya perbedaaan cara subjek mengetahui permasalahan yang membuat kedua orangtuanya sering bertengkar mempengaruhi adversity quotient. Pada subjek pertama DB, orangtua subjek tidak pernah bertengkar secara terang-terangan di depan subjek. Hal ini membuat subjek tidak ingin terlihat bersedih terutama di depan kedua orangtuanya. Adapun dimensi adversity quotient yang dimiliki DB ialah: control (kendali diri), origin-ownership (asal-usul dan pengakuan), reach (jangkauan), dan endurance (daya tahan). Sedangkan subjek kedua, orangtua subjek tetap bertengkar secara terang-terangan walaupun di depan subjek. Hal ini membuat subjek lebih banyak berdiam diri di dalam kamar dan jarang berbagi cerita dengan kedua orangtuanya. Melalui cara seperti ini membuat subjek $\mathrm{S}$ memiliki tiga dimensi adversity quotient yaitu: control (kendali diri), origin-ownership (asal-usul dan pengakuan), dan endurance (daya tahan).

Adapun faktor yang mempengaruhi adversity quotient remaja kedua subjek penelitian ini ialah keyakinan, dimana subjek yakin dengan kemampuan yang dimiliki dalam menyelesaikan setiap permasalahan yang terjadi. Faktor kedua adalah karakter dari kedua subjek, subjek lebih memilih untuk berusaha sendiri dalam 
menyelesaikan setiap permasalahannya. Faktor ketiga yaitu pendidikan, subjek belajar tentang kemandirian, ketegasan, dan dapat bertemu dengan banyak orang serta memiliki banyak teman dengan mengikuti berbagai kegiatan organisasi. Terakhir faktor lingkungan, subjek sudah terbiasa hidup dalam lingkungan yang sulit.

Dapat ditarik kesimpulan bahwa adversity quotient remaja yang mengalami broken home memiliki adversity quotient yang tidak jauh berbeda walaupun memiliki latar belakang permasalahan yang berbeda dalam keluarga yang dilihat dari hasil pembahasan dalam penelitian ini.

\section{DAFTAR RUJUKAN}

Ahmadi R. (2014). Metodologi Penelitian Kualitatif. Yogyakarta. Ar-Ruzz Media.

Atriel (2008) Broken Home. . Diakses pada tanggal 27 April 2018. Diakses dari www.atril.wordpress.com/2008/10/17/pe ngertian-broken-home/

Hurlock, E.B. Alih bahasa Isti Widayanti dan Sudjarwo. (1999). Psikologi Perkembangan Suatu Pendekatan Sepanjang Rentan Kehidupan. Jakarta. Erlangga.

Sugiyono. (2016). Metode Penelitian. Bandung. Alfabeta.

Stoltz. G.P (2000). Adversity Quotient. Mengubah Hambatan menjadi Peluang. Jakarta. Grasindo.

(2005). Adversity Quotient. Mengubah Hambatan menjadi Peluang. Jakarta. Grasindo.

Ulwan, AN (2002). Pendidikan Anak dalam Islam. Jakarta: Pustaka Amani. 